\title{
Klimaschutz, Ressourcenschonung und Circular Economy als Einheit denken
}

\author{
Mario Schmidt ${ }^{1}$
}

Angenommen: 2. November 2021 / Online publiziert: 16. November 2021

(c) Der/die Autor(en) 2021

Schlüsselwörter Klimabilanz $\cdot$ Lebensweg-Ansatz $\cdot$ Ressourceneffizienz $\cdot$ Energiesystemforschung

\section{Thinking of climate protection, resources conservation and the circular economy as a unit}

\author{
Keywords Recycling · Carbon Accounting · Life Cycle Assessment · Resource Efficiency · Energy System Research
}

Der European Green Deal steht faktisch auf zwei Säulen: Um die Netto-Emissionen von Treibhausgasen (THG) bis 2050 auf Null zu reduzieren, ist eine Transformation erforderlich, die insbesondere die Energiewirtschaft, aber auch alle anderen emissionsrelevanten Sektoren betrifft. Daneben steht die Circular Economy, die den Druck auf die natürlichen Ressourcen reduzieren und ein nachhaltiges Wachstum ermöglichen soll. Dabei geht es um den schonenden Umgang mit Materialien, vor allem durch Recycling, aber auch durch andere Formen der nachhaltigeren Nutzung von Materialien wie Reuse, Repair, Refurbishing oder alternativen Geschäftsmodellen.

Im Fokus steht also immer wieder der Umgang mit Energie und Materialien. Bislang werden diese Bereiche meistens separat behandelt: der Klimaschutz und die Energiewende auf der einen Seite und die Ressourceneffizienz und -schonung auf der anderen. Doch beide Themen sind unmittelbar miteinander verbunden: Der Umbau der Energiewirtschaft und der Ausbau der regenerativen Energien wird zwar den Einsatz von fossilen Energieträgern deutlich reduzieren und damit auch die Treibhausgasemissionen, allerdings werden dafür Erzeugungstechnologien und Infrastrukturen benötigt, die große Mengen an Materialien benötigen, darunter auch viele sogenannte kritische Materialien. Gerade der Wechsel von fossilen zu regenerativen Energie-

Mario Schmidt

mario.schmidt@hs-pforzheim.de

1 Institute for Industrial Ecology (INEC), Hochschule Pforzheim, Tiefenbronner Str. 65, 75175 Pforzheim, Deutschland technologien bedarf eines gesteigerten Materialeinsatzes, da die Energiedichte der regenerativen Quellen deutlich geringer ist als bei den fossilen Energieträgern und die Energie quasi materialaufwendig eingesammelt werden muss. Die Bereitstellung der Materialien ist ohne den Einsatz von Energie nicht möglich. Hier besteht eine direkte Rückkopplung zwischen Energie und Materialien.

Auch die Circular Economy funktioniert nicht ohne Energie und damit bislang - und wahrscheinlich auch noch für viele Jahrzehnte - nicht ohne THG-Emissionen. Zwar kann Circular Economy einen wesentlichen Beitrag zum Klimaschutz leisten, weil Recycling von Materialien energetisch oft günstiger ist als die neue Gewinnung aus Bergwerken. Aber es gibt auch Grenzen, wo Recycling nicht mehr sinnvoll ist, z.B. wenn die Dissipation von wichtigen Stoffen in der Technosphäre zu groß ist und das Einsammeln und Trennen einfach zu aufwendig wird. Je geringer die Konzentration der Stoffe im Abfall wird, desto größer wird beim Recycling der Energieaufwand und damit auch die verbundenen THG-Emissionen.

Diese Aspekte sind in der Fachwelt seit langem bekannt, auch wenn sie in der öffentlichen und politischen Diskussion kaum eine Rolle spielen. Besonders problematisch ist aber, dass die politischen Steuerungssysteme solche Wechselwirkungen zwischen der Energie- und der Materialfrage kaum berücksichtigen. Dies soll an einem Beispiel erläutert werden.

Die nationale Klimaschutzpolitik ist seit den Beschlüssen von Kyoto und den Folgekonferenzen an der Verringerung der jeweils nationalen THG-Emissionen ausgerichtet, d.h. jede Nation versucht die Emissionen auf ihrem Territorium zu reduzieren. Das ist auch sinnvoll und dement- 


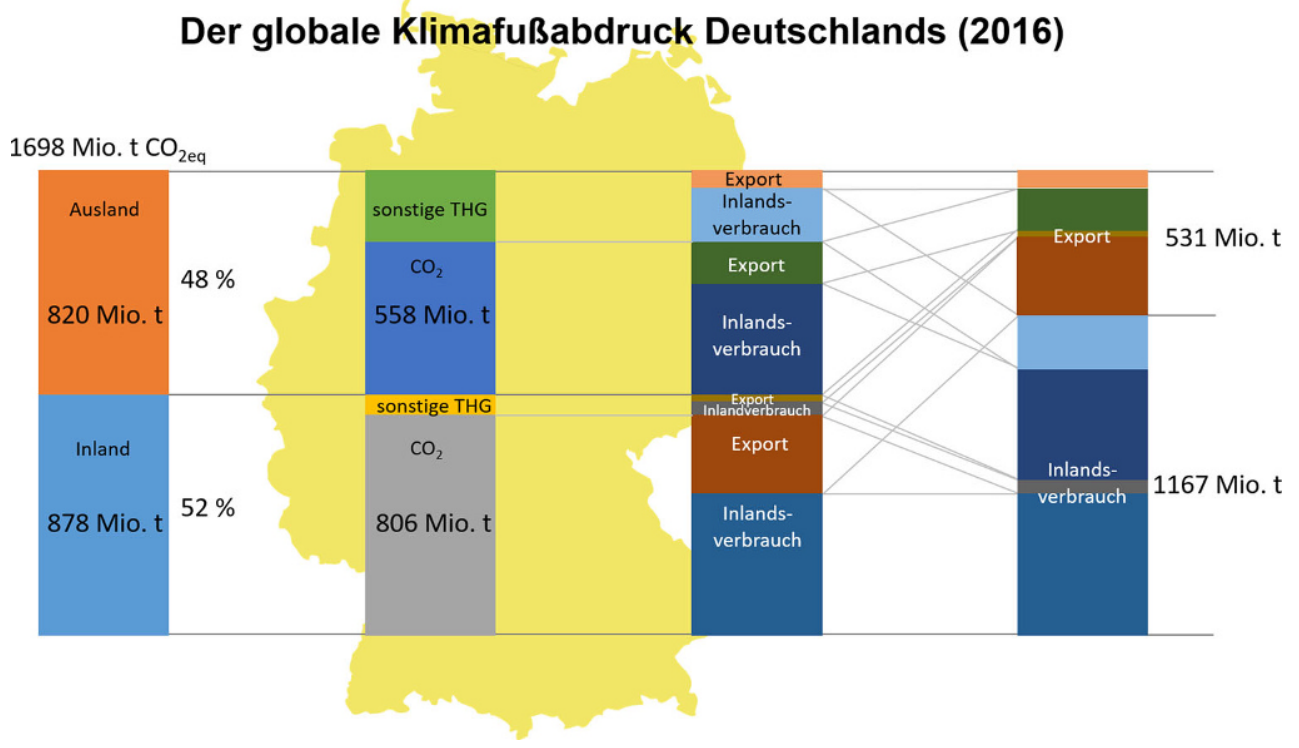

Abb. 1 Die Emissionen (in Tonnen $\mathrm{CO}_{2}$ - Äquivalent), die im deutschen Inland und durch den Import von Gütern außerhalb Deutschlands verursacht werden. Sie werden nach dem Beitrag der verschiedenen Treibhausgasemissionen (THG) unterteilt (2. Balken von links) und diese wiederum nach dem Zweck der Emissionen, also dem Inlandsverbrauch in Deutschland bzw. dem Export von Gütern (rechts). (Quelle der Daten: Schmidt et al. 2021)

Fig. 1 Emissions (in tons of $\mathrm{CO}_{2}$ equivalent) caused in Germany ("Inland") and by the import of goods outside Germany ("Ausland"). They are subdivided according to the contribution of the different green house gases ("THG", 2nd bar from the left) and these in turn according to the purpose of the emissions, i.e. domestic consumption in Germany ("Inlandsverbrauch") or export of goods (right). (Source of data: Schmidt et al. 2021)

sprechend wurde in den vergangenen Jahrzehnten ein umfangreiches Monitoring- und Bilanzierungssystem zu den THG-Emissionen aufgebaut. In Deutschland beispielsweise werden Jahr für Jahr die THG-Emissionen auf dem Gebiet Deutschlands bilanziert und dementsprechend die Minderungspläne, insbesondere in der Energiepolitik, ausgerichtet. Im Jahr 2016 wurden circa 900 Mio. t CO 2 - ̈̈quivalent freigesetzt (Umweltbundesamt 2021).

Doch diese Bilanzen sind nur die Hälfte der Wahrheit (siehe Abb. 1). Denn berechnet man, was Deutschland an THG-Emissionen verursacht, so müssen auch jene Emissionen mit einbezogen werden, die in der Lieferkette für die Bereitstellung von erforderlichen Rohstoffen und Gütern in anderen Ländern erfolgen und das waren im Jahr 2016 zusätzlich etwa 820 Mio. t CO 2 - ̈̈quivalent (Schmidt et al. 2021). Dafür ist Deutschland mitverantwortlich, durch den inländischen Konsum und Investitionen, durch die Produktion von Gütern, wobei einige davon wieder in den Export weitergereicht werden. Bisher war meistens die Argumentation, dass der Klimarucksack der Importgüter sich mit dem Klimarucksack der Exportgüter ausgleicht, so haben es die Zahlen des Statistischen Bundesamtes bislang nahegelegt (Destatis 2019). Doch neue Berechnungen zeigen, dass der Klimarucksack der Importgüter nach Deutschland viel größer ist als bislang angenommen wurde (Schmidt et al. 2021). Dieses Ungleichgewicht der „embodied emissions" von Import- und Exportgütern trifft auch auf Europa insgesamt zu, wie Untersuchungen über die globalen Wirtschaftsverflechtungen und Emissionen zeigen (Wood et al. 2019).

Während also die Energiepolitik insbesondere auf die territorialen Emissionsbilanzen fixiert ist, muss bei der Ressourcenpolitik die gesamte Lieferkette betrachtet werden vom Bergwerk über die Produktherstellung und Nutzungsphase bis zur Entsorgung oder dem Recycling. Viele der ökologischen und sozialen Auswirkungen, die dabei entstehen, sind über die ganze Welt verteilt. Sie lassen sich nur mit Lebenswegansätzen vernünftig erfassen. Das methodische Instrumentarium dafür wurde in den vergangenen Jahrzehnten mit dem Life Cycle Assessment oder dem Carbon Footprint geschaffen und auch international als ISO-Standards normiert.

Man könnte meinen, dass dies für die konkrete Politik kein Problem sei, man ja trotzdem wisse, was in der Energie- und Ressourcenpolitik jeweils zu tun ist. Dies ist aber ein Irrtum und das kann an zwei einfachen und zugegebenermaßen provokativen Beispielen gezeigt werden.

- Reduziert man in Deutschland den Konsum von südamerikanischen Rindersteaks, was bekanntermaßen besonders klimaschädlich ist, so leistet man damit keinen Beitrag zum Erreichen der nationalen Klimaschutzziele in Deutschland. Denn diese Maßnahme wird in keiner offiziellen Bilanz mitberücksichtigt, die eingesparten 
Emissionen würden außerhalb des deutschen Territoriums liegen. Trotzdem ist es aus globaler Klimasicht sinnvoll.

- Die chemische und pharmazeutische Industrie trägt mit 40 Mio. Tonnen jährlich zu den $\mathrm{CO}_{2}$-Emissionen Deutschlands bei (VCI 2021). Würde man sie schließen, wäre dies für die deutsche Klimabilanz positiv. Aber die Chemikalien würden woanders auf der Welt produziert werden. Wahrscheinlich würde Deutschland seinen Chemikalienbedarf dann sogar durch den verstärkten Import decken. Das würde aber in keiner offiziellen Bilanz in Deutschland berücksichtigt werden.

Zum letzten Beispiel noch ein paar Zahlen (Abb. 2): Wenn man von den Dutzend wichtigsten Chemikalien ausgeht, die derzeit in Deutschland produziert werden, so kommt man auf Emissionen von 28 Mio. $\mathrm{t} \mathrm{CO}_{2}$ pro Jahr. Ein großer Wert, der sich einsparen ließe. Wenn die gleiche Menge dann in China produziert würde, so lägen unter Annahme aktueller Emissionsfaktoren die $\mathrm{CO}_{2}$-Emissionen bei 56 Mio. $t$ jährlich, also doppelt so hoch. Selbst wenn man davon ausginge, dass die Chemikalien dann in den USA hergestellt würden, läge der Wert immer noch bei 30 Mio. $\mathrm{t} \mathrm{CO}_{2}$, also höher als in Deutschland. Für den globalen Klimaschutz wäre das also unsinnig. Trotzdem würde die Verlagerung der chemischen Industrie aus rein bilanzieller Sicht positiv bewertet werden.

Auch die Klimawirkung der Circular Economy kann nur im globalen Kontext sinnvoll beurteilt werden. Betrachtet man das Recycling beispielsweise als einen Beitrag zur Versorgungssicherheit bei Rohstoffen, so sollten die Materialkreisläufe in Deutschland oder zumindest in Europa geschlossen werden. Denn eine Aufbereitung der Sekundärrohstoffe in Fernost würde zu weiteren wirtschaftlichen Abhängigkeiten führen. Das hätte aber zur Folge, dass das Recycling zu mehr Emissionen in Europa führt, die beträchtlichen Einsparungen bei der dann geringeren Primärrohstoffgewinnung aber anderenorts in der Welt erfolgt.

Die Bilanzierung der THG-Emissionen, für die wir durch unser Handeln in Deutschland verantwortlich sind, muss also die globale Dimension stets mitberücksichtigen, weil es sonst zu Fehlbewertungen bei Maßnahmen kommt. Während die territoriale Bilanz gut die direkten und vor allem die durch den fossilen Energieeinsatz bedingten Emissionen abbildet, lässt sich der Klimafußabdruck von Rohstoffen und Materialien nur durch Lebenswegansätze und globale Bilanzen realistisch abschätzen. Zukünftig müssen sowohl der Energie- als auch der Materialeinsatz systemisch berücksichtigt werden.

Das führt uns zu dem Thema dieses Heftes. Es ist das Ergebnis eines kooperativen Promotionskollegs in BadenWürttemberg, das zwischen unterschiedlichen Forschergruppen durchgeführt wurde und unter anderem dem Aus- tausch der verschiedenen fachlichen Sichtweisen diente. Beim Karlsruher Institut für Technologie (KIT) beschäftigt sich die Forschergruppe um Prof. Dr. Wolf Fichtner mit der Energiesystemmodellierung, überwiegend aus einer Makroperspektive. Prof. Dr. Armin Grunwald steht dem KIT-Institut für Technikfolgenabschätzung und Systemanalyse vor. Prof. Dr. Ursula Eicker leitete bis 2019 eine Arbeitsgruppe an der Hochschule für Technik in Stuttgart, die sich mit erneuerbaren Energiesystemen aus einer Mikroperspektive befasst. Das Institut für Industrial Ecology (INEC) an der Hochschule Pforzheim mit Prof. Dr. Mario Schmidt und Prof. Dr. Ingela Tietze hat dagegen stärker den Materialmetabolismus der Industriegesellschaft und das Ressourcenthema im Blick und kommt aus dem Bereich ökobilanzieller Analysen. Allen Beteiligten des Kollegs sind die systemische Herangehensweise und die Fächergrenzen überwindende Interdisziplinarität gemein. Durch die Arbeiten zu den Energiesystemen einerseits und den Rohstoffthemen andererseits wurde hier zwischen den Forschern wichtige Brücken geschlagen und Denkanstöße gegeben. Es kam zu Diskussionen unter den jungen Wissenschaftlern, auch zu gemeinsamen Publikationen. Teilweise schlugen sich die neuen Erkenntnisse in den Doktorarbeiten nieder, in denen diese unterschiedlichen Sichtweisen stärker einbezogen oder Berechnungsmodelle entsprechend erweitert wurden. Aber es ist erst ein Anfang, da jede Disziplin bereits hochkomplexe Modelle aufgebaut hat. An diesen Themen wird man weiterarbeiten müssen.

Das Promotionskolleg „Energiesysteme und Ressourceneffizienz" wurde vom Ministerium für Wissenschaft und Kultur des Landes Baden-Württemberg im Rahmen der Landesgraduiertenförderung von 2016 bis 2020 finanziert. Insgesamt konnten 12 Stipendiaten gefördert werden. Bis April 2021 entstanden aus dem Kolleg heraus über 30 begutachtete Fachartikel und genauso viele Beiträge in nichtbegutachteten Zeitschriften bzw. auf Fachtagungen. Einige Doktorarbeiten sind bereits erfolgreich abgeschlossen, andere befinden sich derzeit in der Endphase. Dieses Schwerpunktheft gibt den jungen Nachwuchswissenschaftlern die Möglichkeit, ihre Forschungsthemen vorzustellen. Die Beiträge wurden auch alle einem Begutachtungsprozess unterzogen.

Die Dissertation von Philipp Schäfer, die inzwischen auch als Buch veröffentlicht wurde (Schäfer 2021), beschäftigt sich mit der wichtigen Frage, welchem Zweck das Recycling von Materialien dient. Bei der derzeit in Öffentlichkeit und Politik populären Circular Economy wird zu schnell auf zweitrangige Indikatoren wie dem Recyclinggrad abgehoben. Aber es wird die Frage vernachlässigt, wie weit Recycling tatsächlich zu einer Verringerung der Umweltbelastung beiträgt und eine Versorgungslücke bei Rohstoffen wirklich schließen kann. Schäfer zeigt zwar die Grenzen von Recycling auf, er steckt damit aber auch den 
Rahmen ab, wo Recycling notwendig ist und noch ausgebaut werden muss, um z.B. den Klimaschutz zu fördern. Wichtige Indikatoren sind dabei der Energiebedarf und der Carbon Footprint der Rohstoffgewinnung - sowohl im Bergbau wie auch im Recycling.

Nadine Rötzer knüpft an diese Fragen an (Rötzer 2021), baut auf der Methodik des Lebenswegansatzes auf und behandelt als Fallbeispiel die Primärgewinnung von Kupfer. Sie erstellt ein generisches und parametrisiertes Modell der Kupfergewinnung, das dazu dient, wesentliche Einflussfaktoren wie z.B. der Kupfergehalt im Erz, geologische oder technische Aspekte einzubeziehen und deren Auswirkung auf den Energiebedarf zu verstehen. Wichtiger Indikator ist dabei der kumulierte Energieaufwand (KEA). Als Ergebnis liefert sie konkrete Daten für die Kupferbereitstellung für Deutschland.

Von der grundsätzlichen Perspektive zum shop floor in produzierenden Unternehmen wechselt Marlene Preiß in ihrer Arbeit (Preiß 2021). Bereits in dem Projekt „100 Betriebe für Ressourceneffizienz“ (Schmidt et al. 2019) und in methodischen Ansätzen wie der Materialflusskostenrechnung (Guenther et al. 2015) wurde aufgezeigt, welchen Beitrag Unternehmen durch betriebliche Effizienzmaßnahmen zur Minderung des Klimawandels leisten können. Über Maßnahmen zur Energieeffizienz, deren Treiber und Hemmnisse wurde bereits viel geschrieben. Weniger ausführlich wurden die Erfolgsfaktoren der Materialeffizienz in Betrieben untersucht. Marlene Preiß kann hier auf einen großen Fundus an Fallbeispielen zurückgreifen. Ein interessanter Aspekt ist die Vernetzung der Unternehmen entlang der Wertschöpfungskette, die derzeit auch im $\mathrm{Zu}$ sammenhang mit der Ermittlung von Treibhausgasemissionen, den sogenannten Scope-3-Emissionen, eine zunehmend wichtige Rolle spielt (Schmidt et al. 2021).

Phosphor ist ein Rohstoff, der unverzichtbar nicht nur für die Wirtschaft, sondern für die Menschheit insgesamt ist. Um ihn ranken sich viele, oft auch dystopische Geschichten, denn die derzeitige Gewinnung und Nutzung ist weit entfernt von einer nachhaltigen Bewirtschaftung. Roukaya Issaoui schlägt hier die Brücke zwischen der Gewinnung von Phosphat in Nordafrika und den Technologien zur Phosphorrückgewinnung aus Abwasser (Issaoui et al. 2021). Methodische Basis ist das Life Cycle Assessment, bei dem viele Indikatoren zur Bewertung der Umweltwirkung zum Einsatz kommen.

Jasmin Friedrich beschäftigt sich auch mit Abwassersystemen (Poganietz et al. 2021), die einerseits erheblich zur öffentlichen Gesundheit in Kommunen beitragen, aber auch energie- und ressourcenintensiv sind und Nährstoffe nicht effizient und effektiv zurückgewinnen. Sie untersucht alternative Systeme, bei denen die Trennung von Abwasser in Grau- und Schwarzwasser erfolgt, aber vor allem auch Energie durch Anschluss an Biogasanlage genutzt werden kann und Ressourcen besser zurückgewonnen werden können. Die integrierten Wasser-Energie-Abfall-Systeme werden anhand der sogenannten Ökoeffizienz analysiert.

Wie kann der Wärmebedarf von Gebäuden in Kommunen simuliert werden, der mögliche Einsatz von zentralen und dezentralen Versorgungssystemen geprüft und die lokalen Entscheidungsträger dabei unterstützt werden? Diese Fragen behandelt Verena Weiler in ihrer Arbeit (Weiler und Eicker 2021). Ein Schwerpunkt der Arbeit ist die Entwicklung eines Datenmodells für Energiesystemkomponenten, um eine automatische Simulation zu ermöglichen. Das Datenmodell ist dabei so aufgebaut, dass für die Zukunft auch der Materialeinsatz der energietechnischen Komponenten als Menge an Stahl, Dämmung, Kabel usw. berücksichtigt werden kann.

Die Zeitkomponente ist von zentraler Bedeutung bei der Versorgung von Stadtquartieren und ganzen Städten mit Strom. Sally Köhler hat die bewährte Simulationsumgebung SimStadt durch die Entwicklung eines Stromlastprofilgenerators mit variabler Auflösung und das Hinzufügen einer stündlich aufgelösten PV-Potenzialanalyse einschließlich einer variablen Wirtschaftsanalyse erweitert (Köhler et al. 2021). Dadurch wird die parallele Bewertung des Potenzials der Photovoltaik mit den damit verbundenen Investitions- und Betriebskosten über die Lebensdauer von Hunderten von Einzelgebäuden möglich. Die Simulationsplattform unterstützt zukünftig die Entwicklung granularer nachhaltiger Energiekonzepte durch einen ganzheitlichen, zeitaufgelösten und gebäudespezifischen Ansatz, um damit den Gebäudebestand nachhaltig und kohlenstoffarm zu transformieren.

Wie entscheidet man bei der Transformation von Energiesystemen in Zukunft zwischen den vielen alternativen Technologien und Maßnahmen? Jann Michael Weinand weist hier auf die Lösung durch mathematische Optimierungsmodelle hin (Weinand et al. 2021). Er hat eine Typologie der zu untersuchenden Energiesysteme erstellt. Darauf basierend hat er repräsentative Energiesysteme ausgewählt, in einem Energiesystemoptimierungsmodell analysiert und auf alle anderen Energiesysteme übertragen. Mit diesem bemerkenswerten Ansatz hat er die Mindestkosten der Energiewende für alle 11.131 deutschen Kommunen von 2015 bis 2035 im vollständig energieautarken Fall ermittelt. Die Methodik eignet sich gut um abzuschätzen, welche Kommunen für Energieautonomie besonders geeignet sind und wie ihre Energiesysteme gestaltet werden könnten.

Daniel Fett analysiert die Nutzerakzeptanz von PVBatteriespeichern und deren wesentliche Einflussfaktoren (Fett et al. 2021). Empirische Ergebnisse deuten darauf hin, dass die Akzeptanz von PV-Batteriespeichern vor allem von Überzeugungen, dem Wissen über Batteriespeicher, der Benutzerfreundlichkeit und dem Nutzen von PVBatteriespeichern beeinflusst wird. Vieles hängt von der 
Wahrnehmung der Nutzer ab, deshalb ist es so wichtig, die Menschen über Batteriespeichersysteme zu informieren und über die aktuelle Lebensdauer von Batterien und bestehende Garantien fundiert aufzuklären.

Als letzter Beitrag in diesem Heft befasst sich Jan Rafael Finck mit dem komplexen Thema des europäischen Strombinnenmarkts (Finck 2021). Börsenkapazitäten haben einen wesentlichen Einfluss auf Marktpreise, Börsen und den Energiemix und bestimmen damit auch den $\mathrm{CO}_{2}$ Fußabdruck der Stromerzeugung. Finck stellt einen Rahmen zur Modellierung von Flow Based Market Coupling vor und analysiert u. a. die Auswirkungen unterschiedlicher Niveaus von regulatorisch induzierten Mindesthandelskapazitäten.

An dieser Stelle sei allen weiteren Kolleginnen und Kollegen gedankt, die an dem Promotionskolleg durch Diskussionen und Betreuung aktiv mitgewirkt haben, insbesondere Prof. Dr. Armin Ardone, Dr. Helmut Lehn, Prof. Dr. Russell McKenna, Dr. Witold-Roger Poganietz, Dr. Christine Rösch, Prof. Dr. Tobias Viere und Prof. Dr. Jörg Woidasky. Ein besonderer Dank gilt dem Land Baden-Württemberg und dem Ministerium für Wissenschaft und Kultur für die Förderung des Promotionskollegs.

\section{Thinking of climate protection, resources conservation and} the circular economy as a unit The European Green Deal is in fact based on two main principles: In order to reduce the net emissions of greenhouse gases (GHG) to zero by 2050 , a transformation is required which particularly affects the energy industry, but also all other emission-relevant sectors. In addition, there is the Circular Economy, which aims to reduce pressure on natural resources and enable sustainable growth. This involves the careful use of materials, primarily through recycling, but also through other forms of more sustainable use of materials such as reuse, repair, refurbishing or alternative business models.

The focus is always on the use of energy and materials. Until now, these areas have mostly been treated separately: Climate protection and energy transition on the one hand, resource efficiency and conservation on the other. But the two topics are directly linked: The restructuring of the energy industry and the expansion of renewable energies will significantly reduce the use of fossil fuels and thus also GHG emissions. However, this requires production technologies and infrastructures that need large quantities of materials, including many so-called critical materials. The change from fossil to renewable energy technologies requires an increased use of materials, since the energy density of renewable sources is significantly lower than that of fossil energy sources and the energy has to be collected in a virtually material-intensive way. The supply of materials is not possible without the use of energy. Here, there is a direct feedback between energy and materials.
The circular economy also does not work without energy, and so far, - and probably for many decades to come- - not without GHG emissions. The circular economy can make a significant contribution to climate protection because recycling materials is often more energy-efficient than extracting new materials from mines. But there are also limits where recycling no longer makes sense, for example, when the dissipation of important substances in the technosphere is too high and the collection and separation simply becomes too complex. The lower the concentration of the substances in the waste, the greater the energy required for recycling and thus also the associated GHG emissions.

These aspects have been known to experts for a long time, even though they hardly play a role in public and political discussions. However, it is particularly problematic that the political control systems hardly consider such interactions between the energy and the material issue. This will be explained by an example.

Since the Kyoto resolutions and the follow-up conferences, national climate protection policy has been geared towards the reduction of the respective national GHG emissions, i.e. each nation attempts to reduce emissions on its territory. This makes sense and, accordingly, an extensive monitoring and accounting system on GHG emissions has been established in recent decades. In Germany, for example, GHG emissions are balanced every year and the reduction plans, especially in the energy policy, are aligned accordingly. In 2016, approximately 900 million tons of $\mathrm{CO}_{2}$ equivalent were released (Umweltbundesamt 2021).

But these balances are only half the truth (see Fig. 1). If we calculate what Germany causes in terms of GHG emissions, then those emissions must also be included in the supply chain that result from the provision of raw materials and goods in other countries, which amounted to an additional 820 million tons of $\mathrm{CO}_{2}$ equivalent (Schmidt et al. 2021) in 2016. Germany is partly responsible for this, through domestic consumption and investment, through the production of goods, some of which are passed on again for export. Until now, the argumentation has mostly been that the climate backpack of imported goods equalizes the climate backpack of exported goods. This is what the figures of the Federal Statistical Office have suggested so far (Destatis 2019). But new calculations show that the climate backpack of imported goods to Germany is much larger than previously assumed (Schmidt et al. 2021). This imbalance of "embodied emissions" of import and export goods also applies to Europe as a whole, as studies on global economic interdependencies and emissions show (Wood et al. 2019).

Thus, while energy policy is particularly focused on territorial emissions balances, resource policy must look at the entire supply chain-from the mine to the product manufacturing and use phase to disposal or recycling. Many of 




Abb. 2 Die THG-Emission (in Mio. t/a) von den mengenmäßig wichtigsten 12 Chemikalien, die in Deutschland derzeit produziert werden, und die potenziellen THG-Emissionen, wenn sie in China bzw. den USA produziert würden

Fig. 2 The GHG emissions (in million t/a) of the 12 most important chemicals currently produced in Germany and the potential GHG emissions if they were produced in China or the USA

the environmental and social impacts that arise are shared across the world. They can only be measured sensibly with life cycle approaches. The methodological tools for this have been created in recent decades in the form of life cycle assessment or the carbon footprint and have also been standardized internationally as ISO standards.

One might think that this would not be a problem for specific policy, since one still knows what has to be done in energy and resource policy in each case. But this is a misconception and can be shown by two simple and admittedly provocative examples.

- Reducing the consumption of South American beef steaks in Germany, which is known to be particularly harmful to the climate, does not contribute to achieving the national climate protection goals in Germany. This measure is not considered in any official balance sheet, and the emissions saved would be outside the German territory. Nevertheless, it makes sense from a global climate perspective.

- The chemical and pharmaceutical industry contributes 40 million tons annually to Germany's $\mathrm{CO}_{2}$ emissions (VCI 2021). If they were closed, this would be positive for the German carbon footprint, but the chemicals would be produced elsewhere in the world. Germany would then probably even cover its chemical needs through increased imports. But this would not be considered in any official balance sheet in Germany.

For the last example, a few more figures (Fig. 2): Assuming the dozen most important chemicals currently produced in Germany, we come up with emissions of 28 million $t$ $\mathrm{CO}_{2}$ per year. A large amount that could be saved. If the same amount were then produced in China, assuming current emission factors, $\mathrm{CO}_{2}$ emissions would be 56 million tons per year, twice as high. Even if we assume that the chemicals would then be produced in the USA, the value would still be 30 million tons of $\mathrm{CO}_{2}$, i.e. higher than in Germany. This would therefore make no sense in terms of global climate protection. Nevertheless, the relocation of the chemical industry would be considered positive from a purely balance sheet perspective.

The climate impact of the circular economy can also only be sensibly assessed in a global context. For example, if recycling is seen as a contribution to the supply reliability of raw materials, the material cycles should be closed in Germany or at least in Europe. This is because a processing of secondary raw materials in the Far East would lead to further economic dependencies. However, this would mean that recycling would lead to more emissions in Europe, but, elsewhere in the world, it would result in significant savings through subsequent reduction of primary raw material extraction.

The accounting of GHG emissions we are responsible for through our actions in Germany must therefore always consider the global dimension, because otherwise measures will be misjudged. While the territorial balance reflects the direct emissions and above all the emissions caused by fossil energy use, the carbon footprint of raw materials and materials can only be realistically estimated using life cycle approaches and global balances. In the future, both energy and material use must be considered systemically.

This leads us to the subject of this issue. It is the result of a cooperative doctoral program in Baden-Württemberg, which was conducted between different research groups and served, among other things, the exchange of different professional perspectives. At the Karlsruhe Institute of Technology (KIT), the research group led by Prof. Dr. Wolf Fichtner deals with energy system modeling, mainly from a macro perspective. Prof. Dr. Armin Grunwald heads the KIT Institute for Technology Assessment and Systems Analysis. Prof. Dr. Ursula Eicker headed a working group at the Stuttgart University of Applied Sciences until 2019, dealing with renewable energy systems from a micro perspective. The Institute for Industrial Ecology (INEC) at Pforzheim University of Applied Sciences with Prof. Dr. Mario Schmidt and Prof. Dr. Ingela Tietze, on the other hand, has a stronger focus on the material metabolism of the industrial society and the resource topic. It has its background in the field of life cycle assessment. All participants of the research group share a systemic approach and an interdisciplinarity that overcomes disciplinary boundaries. Through the work on energy systems on the one hand and raw material topics on the other, important bridges were built between the researchers and impulses for thought were given. There were discussions among the young scientists, including joint 
publications. In some cases, the new findings were reflected in the doctoral theses, in which these different perspectives were more closely integrated or calculation models were expanded accordingly. But it is only a beginning, as each discipline has already built highly complex models. Further work will have to be done on these topics.

The doctoral program "Energy Systems and Resource Efficiency" was financed by the Ministry of Science and Culture of the State of Baden-Württemberg within the framework of the state graduate funding from 2016 to 2020 . A total of 12 scholarship holders received funding. By April 2021, the doctoral program had produced over 30 peer-reviewed articles and just as many contributions in non-peerreviewed journals or at academic conferences. Some doctoral theses have already been successfully completed, others are currently in the final phase. This publication gives young scientists the opportunity to present their research topics. The contributions were also all subject to a review process.

Philipp Schäfer's dissertation, which has since also been published as a book (Schäfer 2021), addresses the important question of what purpose the recycling of materials serves. In the Circular Economy, which is currently popular in the public and in politics, the emphasis is too quickly placed on secondary indicators such as the degree of recycling. But it neglects the question of how far recycling actually contributes to a reduction in environmental impact and can really close a supply gap in raw materials. Schäfer does point out the limits of recycling, but in doing so he also sets out the framework where recycling is necessary and still needs to be expanded in order to promote climate protection, for example. Important indicators are energy demand and the carbon footprint of raw material extraction-both in mining and recycling.

Nadine Rötzer follows up on these questions (Rötzer 2021), builds on the methodology of the life cycle approach and treats the primary extraction of copper as a case study. She creates a generic and parameterized model of copper extraction, which is used to include significant influencing factors such as the copper content in the ore, geological or technical aspects and to understand their impact on the energy demand. The important indicator here is the cumulative energy demand (CED). As a result, it provides concrete data for copper supply for Germany.

In her work, Marlene Preiß switches from the basic perspective to the shop floor in manufacturing companies (Preiß 2021). The project "100 Companies for Resource Efficiency" (Schmidt et al. 2019) and methodological approaches such as material flow cost accounting (Guenther et al. 2015) have already shown what contribution companies can make to climate change mitigation through operational efficiency measures. Much has already been written about energy efficiency measures, their drivers and barriers. Less detailed research has been done on the success factors of material efficiency in companies. Marlene Preiß can draw on a large pool of case studies. One interesting aspect is the networking of companies along the value chain, which is currently also playing an increasingly important role in connection with the determination of GHG emissions, the so-called Scope 3 emissions (Schmidt et al. 2021).

Phosphorus is a raw material that is indispensable not only for the economy, but for humanity as a whole. Many, often dystopian, stories are woven around it, because current extraction and use is far from sustainable management. Here, Roukaya Issaoui bridges the gap between the extraction of phosphate in North Africa and the technologies for phosphorus recovery from wastewater (Issaoui et al. 2021). The methodological basis is Life Cycle Assessment, which uses many indicators to evaluate the environmental impact.

Jasmin Friedrich is also working on wastewater systems (Poganietz et al. 2021), which on the one hand contribute significantly to public health in municipalities, but are also energy and resource intensive and do not recover nutrients efficiently and effectively. She is investigating alternative systems that separate wastewater into gray and black water, but more importantly, these systems can also utilize energy by connecting it to biogas plants and recover resources more efficiently. The integrated water-energy-waste systems are analyzed based on the so-called eco-efficiency.

How can the heat demand of buildings in municipalities be simulated, the possible use of centralized and decentralized supply systems be examined, and local decisionmakers be supported in the process? In her work, Verena Weiler addresses these questions (Weiler and Eicker 2021). One focus of it is the development of a data model for energy system components to enable automatic simulation. The data model is set up in such a way that, for the future, the material input of the energy-technical components can also be considered as the quantity of steel, insulation, cables, etc.

The time component is of central importance in supplying urban neighborhoods and entire cities with electricity. Sally Köhler has extended the established simulation environment SimStadt with the development of a current load profile generator with variable resolution and an hourly PV potential analysis with variable economic analysis (Köhler et al. 2021). This enables the parallel evaluation of the potential of photovoltaics with the associated investment and operating costs over the lifetime of hundreds of individual buildings. In the future, the simulation platform will support the development of granular sustainable energy concepts through a holistic, time-resolved and buildingspecific approach, thereby transforming the building stock in a sustainable and low-carbon manner.

How does one decide between the many alternative technologies and measures in the transformation of energy sys- 
tems in the future? Jann Michael Weinand points to the solution by mathematical optimization models (Weinand et al. 2021). He has created a typology for the energy systems to be examined. Based on this, he has selected representative energy systems, analyzed them in an energy system optimization model, and applied it to all other energy systems. Using this remarkable approach, he determined the minimum costs of the energy transition for all 11,131 German municipalities from 2015 to 2035 in the fully energy selfsufficient case. The methodology is well suited to estimate which municipalities are particularly suitable for energy autonomy and how their energy systems could be designed.

Daniel Fett analyzes the user acceptance of PV battery storage and its major influencing factors (Fett et al. 2021). Empirical results indicate that the acceptance of PV battery storage is mainly influenced by beliefs, knowledge about battery storage, user-friendliness, and benefits of PV battery storage. Much depends on user perceptions, which is why it is so important to inform people about battery storage systems and provide sound information about current battery life and existing warranties.

As the last article in this issue, Jan Rafael Finck deals with the complex topic of the European electricity market (Finck 2021). Stock exchange capacities have a significant impact on market prices, exchanges, and the energy mix, and thus also determine the carbon footprint of electricity generation. Finck presents a framework for modeling flowbased market coupling and analyzes, among other things, the impact of different levels of regulatory induced minimum trading capacities.

At this point, we would like to thank all other colleagues who have actively contributed to the doctoral program through discussions and supervision, in particular Prof. Dr. Armin Ardone, Dr. Helmut Lehn, Prof. Dr. Russell McKenna, Dr. Witold-Roger Poganietz, Dr. Christine Rösch, Prof. Dr. Tobias Viere and Prof. Dr. Jörg Woidasky. Special thanks go to the state of Baden-Württemberg and the Ministry of Science and Culture for funding the doctoral program.

Funding Open Access funding enabled and organized by Projekt DEAL.

Interessenkonflikt M. Schmidt gibt an, dass kein Interessenkonflikt besteht.

Open Access Dieser Artikel wird unter der Creative Commons Namensnennung 4.0 International Lizenz veröffentlicht, welche die Nutzung, Vervielfältigung, Bearbeitung, Verbreitung und Wiedergabe in jeglichem Medium und Format erlaubt, sofern Sie den/die ursprünglichen Autor(en) und die Quelle ordnungsgemäß nennen, einen Link zur Creative Commons Lizenz beifügen und angeben, ob Änderungen vorgenommen wurden.

Die in diesem Artikel enthaltenen Bilder und sonstiges Drittmaterial unterliegen ebenfalls der genannten Creative Commons Lizenz, sofern sich aus der Abbildungslegende nichts anderes ergibt. Sofern das betreffende Material nicht unter der genannten Creative Commons Lizenz steht und die betreffende Handlung nicht nach gesetzlichen Vorschriften erlaubt ist, ist für die oben aufgeführten Weiterverwendungen des Materials die Einwilligung des jeweiligen Rechteinhabers einzuholen.

Weitere Details zur Lizenz entnehmen Sie bitte der Lizenzinformation auf http://creativecommons.org/licenses/by/4.0/deed.de.

\section{Literatur}

Destatis (2019) Umweltökonomische Gesamtrechnung: Direkte und indirekte $\mathrm{CO}_{2}$-Emissionen in Deutschland 2010-2015. Bericht 5851305-19900-4. DeStatis, Wiesbaden.

Fett D, Dehler-Holland J, Schmutz M (2021) A survey on the user acceptance of PV battery storage systems. NachhaltigkeitsManagementForum. https://doi.org/10.1007/s00550-021-00513-9

Finck R (2021) Impact of flow based market coupling on the European electricity markets. NachhaltigkeitsManagementForum

Guenther E, Jasch C, Schmidt M, Wagner B, Ilg P (2015) Material flow cost accounting: looking back and ahead. J Clean Prod 108(Part B):1249-1254. https://doi.org/10.1016/j.jclepro.2015.10.018

Issaoui R, Rösch C, Woidasky J, Schmidt M, Viere T (2021) Cradleto-gate life cycle assessment of beneficiated phosphate rock production in Tunisia. NachhaltigkeitsManagementForum

Köhler S, Betz M, Duminil E et al (2021) A holistic approach to model electricity loads in cities. NachhaltigkeitsManagementForum. https://doi.org/10.1007/s00550-021-00516-6

Poganietz WR, Friedrich J, Lehn H (2021) Eco-efficiency of system alternatives of the urban water-energy-waste nexus. NachhaltigkeitsManagementForum. https://doi.org/10.1007/s00550-02100517-5

Preiß M (2021) Treiber und Hemmnisse betrieblicher Effizienzmaßnahmen - Vernetzung als Erfolgsfaktor. NachhaltigkeitsManagementForum. https://doi.org/10.1007/s00550-021-00512-w

Rötzer N (2021) Energetischer Aufwand der Bereitstellung von Primärkupfer in Deutschland. NachhaltigkeitsManagementForum. https://doi.org/10.1007/s00550-021-00518-4

Schäfer P, Schmidt M (2021) Recycling - ein Mittel zu welchem Zweck? Springer Spektrum, Wiesbaden. https://doi.org/10.1007/ 978-3-658-32924-2

Schmidt M, Nill M, Scholz J (2021) Die Bedeutung der Lieferkette für den Klimafußabdruck von Unternehmen. Chem Ing Tech 93(11):1692-1706. https://doi.org/10.1002/cite.202100126

Schmidt M, Spieth H, Haubach C, Kühne C (2019) 100 Pioneers in Efficient Resource Management. Springer Spektrum, Berlin, Heidelberg https://doi.org/10.1007/978-3-662-56745-6

Umweltbundesamt (2021) Berichterstattung unter der Klimarahmenkonvention der Vereinten Nationen und dem Kyoto-Protokoll 2021: Nationaler Inventarbericht zum Deutschen Treibhausgasinventar 1990-2019. Climate Change 43/2021. Umweltbundesamt, Dessau

VCI (2021) Chemiewirtschaft in Zahlen. Verband der Chemischen Industrie. VCI, Frankfurt/M.

Weiler V, Eicker U (2021) Automatic energy demand and system simulation at district level. NachhaltigkeitsManagementForum. https:// doi.org/10.1007/s00550-021-00519-3

Weinand JM, McKenna R, Fichtner W (2021) The feasibility of energy autonomy for municipalities: local energy system optimisation and upscaling with cluster and regression analyses. NachhaltigkeitsManagementForum. https://doi.org/10.1007/s00550-02100514-8

Wood R, Neuhoff K, Moran D, Simas M, Grubb M, Stadler K (2019) The structure, drivers and policy implications of the European carbon footprint. Clim Policy 20(sup1):S39-S57. https://doi.org/10. 1080/14693062.2019.1639489

\section{Mario Schmidt Guest Editor}

